\begin{tabular}{l|l|l}
\hline & $\begin{array}{l}\text { Proceedings of the } \\
\text { Informing Science }+\end{array}$ & $\begin{array}{l}\text { An Official Publication } \\
\text { of the Informing Science Institute } \\
\text { InformingScience.org }\end{array}$ \\
\hline $\begin{array}{l}\text { Information Technology } \\
\text { Education Conference }\end{array}$ & \begin{tabular}{l} 
InformingScience.org/Publications \\
\hline
\end{tabular}
\end{tabular}

Online July 6-7, 2021

\title{
The Flipped ClassRoom Model in Libyan Higher EDUCATION: EXPERIENCES WITH STUDENTS OF COMPUTER PRINCIPLES
}

\begin{tabular}{ll}
\hline Entisar Alhadi Al Ghawail * & $\begin{array}{l}\text { Alasmarya Islamic University, Zliten, e.alghawail@asmarya.edu.ly } \\
\text { Libya and } \\
\text { Faculty of Sciences, University of } \\
\text { Tunis El Manar, Tunisia }\end{array}$ \\
& $\begin{array}{l}\text { Department of Software Science, Sadok.ben@, taltech.ee } \\
\text { Sallinn University of Technology, } \\
\text { Estonia }\end{array}$ \\
&
\end{tabular}

\begin{abstract}
Aim/Purpose This study aims to examine the effectiveness of the flipped learning approach in a computer principles course at Alasmarya Islamic University, Libya.

Background The reason for this consideration was to evaluate the viability of conventional lecture-based educational programmes versus the active learning of computer concepts in flipped classrooms for college economics students at the Alasmarya Islamic University.

Methodology The experiment was applied to two groups: one, class A, undertook the course through the traditional method, while the other, class B, undertook the course according to the flipped classroom model. Class A students had to attend a face-to-face classroom lecture, while Class B students had to watch a pre-recorded YouTube lecture before attending class.
\end{abstract}

Findings The findings show that students participating in the flipped classroom were satisfied with this model, which produced a positive effect on students' achievements in higher education. The flipped model also has the ability to increase students' motivation to teach themselves compared with the traditional model.

\footnotetext{
Accepted by Editor Michael Jones | Received: December 27, 2020 | Revised: May 5, May 10, 2021 | Accepted: May 11, 2021.

Cite as: Al Ghawail, E. A., \& Ben Yahia, S. (2021). The flipped classroom model in Libyan higher education: Experiences with students of computer principles. In M. Jones (Ed.), Proceedings of InSITE 2021: Informing Science and Information Technology Education Conference, Article 15. Informing Science Institute. https://doi.org/10.28945/4778
}

(CC BY-NC 4.0) This article is licensed to you under a Creative Commons Attribution-NonCommercial 4.0 International License. When you copy and redistribute this paper in full or in part, you need to provide proper attribution to it to ensure that others can later locate this work (and to ensure that others do not accuse you of plagiarism). You may (and we encourage you to) adapt, remix, transform, and build upon the material for any non-commercial purposes. This license does not permit you to use this material for commercial purposes. 
Recommendations This study recommends the use of flipped learning paradigm to teach in for Practitioners higher education in Libya, as the teachers who applied flipped learning may also provide students with the opportunity to practice and improve their independent learning.

Keywords

flipped classroom, flipped learning, effectiveness of flipping learning, flipped model, Libyan higher education

\section{INTRODUCTION}

For decades, education around the world has contributed an enormous sum of assets in preparing people to meet the prerequisites of society. In 2015, the developing countries propelled the feasible advancement objectives, which must be fulfilled by 2030 and the objective of this activity is related to worldwide instruction (Evseeva \& Solozhenko, 2015). In response to this activity, a few teachers in each nation have attempted to contribute to this objective. One of these is the Alasmarya Islamic University in Libya. A long time ago, a learner programme was propelled to move forward the educating abilities of faculty individuals, where specialists within the areas of instructional method and related areas guided the training programme. In the traditional model of teaching, the teacher gives the students learning material in the course of the lecture and during group discussions, and then the teacher offers them homework. (Hsieh et al., 2017). The flipped classroom is a teaching model in which a student's homework is the traditional lecture viewed outside of class on a video. Then, the class time is spent on inquiry-based learning, including what would traditionally be considered a student's homework assignment. One advantage of the flipped model is the ability of teachers to access formatively a student's homework deficiencies immediately in class. Likewise, corrective materials can be posted online and made available anytime and anywhere there is an Internet connection (Soliman, 2016).

The flipped model is designed for acquiring knowledge at the individual level; the objective of this paper is to assess the viability of the flipped classroom strategy in its application to an instructive subject at one of the Libyan universities (García-Ramírez, 2019). Indeed, when students carry out their learning from home, the teacher can also provide them with online communication regarding the relevant learning materials, as these must be distributed properly to all participants (Le \& Do, 2019). The goal of this study is to find answers to the following questions:

Q1. How effective is the flipped approach in the classroom?

Q2. Is there a significant difference in results between learning in a traditional classroom and a flipped classroom when it comes to computer principles?

We organize the rest of this study as follows: The next section presents a literature review of the flipped classroom demonstration, counting a few consider within the field of computer science. The third section presents materials and strategies counting subtle elements approximately test estimate, course show and structure, and information collection. The fourth describes the findings from the data gathered by the questionnaire. The central conclusions are provided in the last section.

\section{SCRUTINY OF RELATED WORK}

The flipped classroom is an adaptive learning paradigm in which students are expected to become more interested in learning. Students do not receive a lecture in this model, as they would do in the traditional model. Instead, they review some academic material before they attend the face-to-face class and make notes on questions or concerns, they might have (Silva \& Quadros, 2019). Mulbar and Zaki (2019) described the flipped classroom as a learning environment in which all learners can gain personalized instruction and experience through activities that support their improvement, enabling students to interact in learning and providing them with a deep understanding of the learning materials. In the view of Karabulut-Ilgu et al., (2018), flipped classrooms build a student-friendly 
environment that motivates learners, and classroom time is used to develop the information that learners have gathered at home, through workbooks, debates, or engaging in exercises that contribute to their critical thinking skills.

"Within the classroom, students take part in more significant academic activities, such as problemsolving sessions, discussions, or games. Through these activities, students develop their self-learning skills" (Suardika et al., 2016). Pastor and Howard (2018) defined flipped learning as "a form of blended learning that has become a prominent new instructional strategy and trend within the last ten years". Figure 1 shows that, in a flipped environment, students learn new material outside the classroom, through online video lectures.

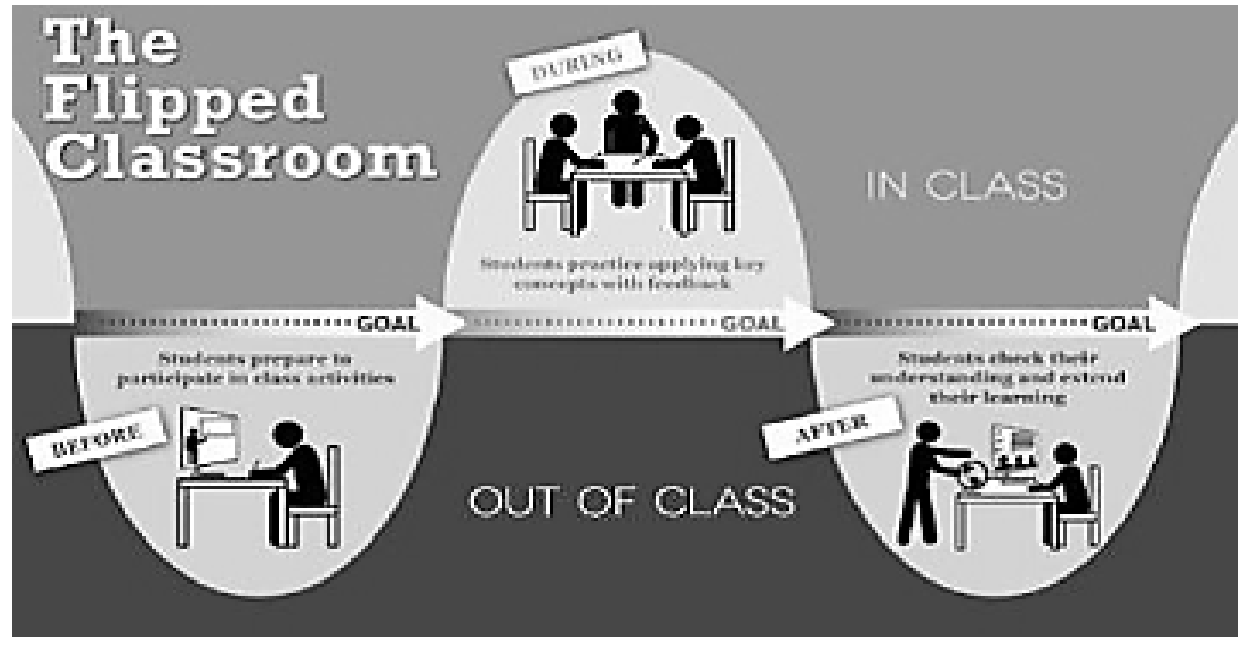

Figure1: The Flipped Classroom Model (Pastor \& Howard, 2018)

\section{LEARNING ACTIVITIES IN THE FLIPPED CLASSROOM}

Flipped classrooms vary from conventional classrooms, ranging from their facilities and activities to their consequences (Suardika et al., 2016). This model should increase student engagement in the classroom and can be extended to higher education in Libya, underscore that the instructor, before implementing the rolling teachers' model, must plan the learning material well. Indeed, students must study for at least 90 minutes at home (Ahmed, 2016; Soliman, 2016). The teacher can also make online correspondence about the learning material available to students at home. The students must know the educational targets for the learning process to be centered. Table 1 shows a list of activities within the flipped educational classroom (Mulbar \& Zaki, 2019).

Table 1: The Activities in the Flipped Classroom (Mulbar \& Zaki, 2019).

\begin{tabular}{|c|l|l|}
\hline The Activity & \multicolumn{1}{|c|}{ Evaluation or Tasks } & Duration \\
\hline Warm-up Activity & $\begin{array}{l}\text { This starts with the lecturer's greeting to the class participants, } \\
\text { checking the student's attendance, and making sure that the } \\
\text { class is ready to study. }\end{array}$ & 15 minutes \\
\hline The second Activity & $\begin{array}{l}\text { The teacher explains the material briefly, discusses the im- } \\
\text { portant aspects of the material, and gives students a chance to } \\
\text { inquire about the problems they faced while learning at home. }\end{array}$ & 45 minutes \\
\hline
\end{tabular}




\begin{tabular}{|c|l|c|}
\hline The Activity & \multicolumn{1}{|c|}{ Evaluation or Tasks } & Duration \\
\hline The third Activity & $\begin{array}{l}\text { The teacher assigns tasks to the class participants while ob- } \\
\text { serving students' participation and understanding during these } \\
\text { tasks. The teacher also explains the solution to students' activi- } \\
\text { ties in the classroom. }\end{array}$ & 45 minutes \\
\hline The final Activity & $\begin{array}{l}\text { Participants are given the next round of lecturing materials by } \\
\text { the teacher to be studied at home, and the teacher also con- } \\
\text { cludes the current lecture. }\end{array}$ & 45 minutes \\
\hline
\end{tabular}

\section{THE ADVANTAGES OF IMPLEMENTING THE FLIPPED CLASSROOM}

The flipped classroom can save time for engaging activities for learners, which allows teachers to utilize class time for discussions and problem solving. Also doing homework in the classroom is better than doing homework at home because students can help each other (Ahmed, 2016). Teachers can give personalized assistance when students are stuck on a problem and can help clarify miscomprehended points (Soliman, 2016). Teachers can also revise some parts of the videos if needed as well as providing feedback to the students. It improves the students' participation in the classroom and improves the quality of teaching. The model allows students to practice before entering the classroom, which ensures that students should have more information before studying in the classroom (O'Flaherty \& Phillips, 2015; Mulbar \& Zaki, 2019).

Previous research has shown that the flipped classroom teaching model leads to good participation by students in the classroom, as well as improving students' cooperation and enabling students to find solutions to the individual difficulties they face in completing their tasks (Evseeva \& Solozhenko, 2015). Sulisworo et al., (2019) found that the instructional model increased the performance of junior high school students in chemistry. Pastor and Howard (2018) and Hsieh et al., (2017) conducted long-term longitudinal studies to investigate the effect of the flipped learning approach to training courses in college technology.

In this study researchers determined self-efficacy and interpretation for college economics students, which was based on the learning expectations of the students. Selected topics were taught using both techniques to compare the adequacy of the flipped classroom compared to the traditional one. In the flipped classroom, learning materials included video recordings, post-tests, and surveys that were available online to the students. Table 2 shows the Duration of the Pre-recorded Lectures of the Flipped Model for Students of Computer Principles in Alasmarya Islamic University.

Table 2: The Duration of the Pre-recorded Lectures of the Flipped Model

\begin{tabular}{|c|c|c|}
\hline Week & Topic & Duration \\
\hline 1 & Introduction to computer science. & $45 \mathrm{~m}$ \\
\hline 2 & The components of computers, hardware and software. & $60 \mathrm{~m}$ \\
\hline 3 & Study of processing triangle, electronic data. & $60 \mathrm{~m}$ \\
\hline 4 & Processing unit central, input units, output units and storage units. & $90 \mathrm{~m}$ \\
\hline 5 & Types of memory: Main memory, RAM and ROM. & $60 \mathrm{~m}$ \\
\hline 6 & Study of system programs, application programs and programming languages. & $90 \mathrm{~m}$ \\
\hline
\end{tabular}




\section{DATA Collection}

The target sample of this study is a random sample of 50 students $(n=50)$ from the Economic College in the $\mathrm{Al}$ Asmarya Islamic University in Libya. Class A studied under the traditional model while Class B undertook the course through the flipped model. Both Class A and Class B had 25 students, both were in the April to July 2019 academic period, and both classes focused on the study of computer principles during the course at the college.

The reason for this study was to evaluate the viability of conventional lecture-based educational programs versus the active learning of computer concepts in flipped classrooms for college economic students at Alasmarya Islamic University and improve the quality of Libyan higher education.

The experiment was applied to two groups: one, the traditional classroom (Class A), undertook the course through the traditional method, while the other, flipped classroom (Class B), undertook the course according to the flipped classroom model. Class A students had to attend a face-to-face classroom lecture, while Class B students had to watch a pre-recorded YouTube lecture before attending class.

Grades were calculated based on what students accomplished throughout the semester. Students and teachers in the flipped classroom (class B) worked together for a group discussion and hands-on exercises during class hours. Fifty students answered the researcher's questions in both classes A and B. The questionnaire had 20 questions related to the course, as follows: Questions 1 to 19, which are shown in Table 6, were based on a five-point Likert scale selecting from strongly agree, agree, neither agree nor disagree, disagree, and strongly disagree. The final question of the questionnaire was an open question to gain suggestions pertaining to students' learning. Students and teachers work together for a group discussion and hands-on exercises during class hours. Students' participation in this study was optional to answer the questions in the questionnaire that was presented to them by the researchers: 25 students were willing to answer the researcher's questions in the flipped classroom (class B).

\section{DATA ANALYSIS}

In this study, descriptive statistics for grades were determined for each category. ANOVA analysis was carried out using a confidence level of 95 percent and the level of significance was set at 5\%.; this study helped to assess if there was a substantial difference between the average scores from classes $\mathrm{A}$ and $\mathrm{B}$.

The questionnaire had 20 questions related to the course: Questions 1 to 19 were based on a fivepoint Likert scale selecting from strongly agree, agree, neither agree nor disagree, disagree, and strongly disagree. The last question of the questionnaire was an open question to gain knowledge and suggestions pertaining to students' learning through the flipping teaching. All analyses were performed using SPSS.

\section{EXPERIMENTAL STUDY-COURSE GRADES}

To test whether the traditional model showed better results than the flipped one, the students' scores were displayed in a table. The maximum score students could get was 50 points, and they required 25 points to pass the course. The percentages of students passing the subject were $62 \%$ for Class A (traditional class) and $76 \%$ for Class $\mathrm{B}$ (flipped class). Figure 2 shows the average of final grades for the two classes. 


\section{Average of grades}

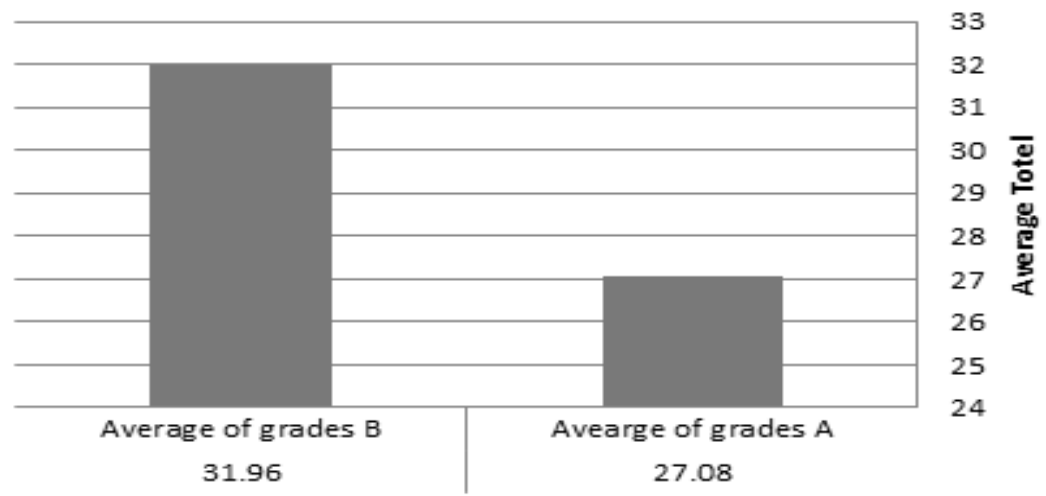

Figure 2: Average of Final Grades for both classes

We carried this study out using the score from the second part of the semester, and it determined the difference between those scores. At the end of the course, eight students from class A got a score that was equal to the score achieved by nine students from class B. Scores from class A differed from those from class $\mathrm{B}$, as the score from the traditional model students in class A is ( $\mathrm{p}$-value $=0.124$ ), which is statistically different from the flipped model students' score in class B ( $\mathrm{p}$-value $=0.121$ ). This means that the flipped classroom model affected the grades of the students. Table 3 shows the final grades and percentages for the two research groups.

Table 3: Final Grades and Student Percentages for Two Research Groups

\begin{tabular}{|l|r|r|r|r|r|r|r|r|}
\hline & Value(t) & Df & Deviation & $\begin{array}{c}\text { Sig. } \\
\text { (2-tailed) }\end{array}$ & Average & Variance & \multicolumn{2}{|c|}{$\begin{array}{c}\text { 95\% Confi- } \\
\text { dence }\end{array}$} \\
\cline { 5 - 9 } & & & & & & Lower & Upper \\
\hline Class A & 11.582 & 24 & 11.69017 & .124 & 27.0800 & 136.660 & 22.2545 & 31.9055 \\
& & & & & & & & \\
Class B & 15.580 & 24 & 10.25703 & .121 & 31.9600 & 105.207 & 27.726 & 36.1939 \\
\hline
\end{tabular}

The results of the questions comparing the traditional model with the flipped model showed that the value $(\mathrm{T})$ became statistically significant at Bloom levels, meaning that there were differences in the average achievement test of the flipped learning class. The average of the test grades for class $\mathrm{A}$ (27.08) was lower than class B (31.96). An analysis was carried out using the SPSS 20.0, which produced a value of 1.146. The test calculated whether the average difference between the two groups was statistically significant. There is a significant relationship between the test scores of flipped learning students and those of traditional class students on the subject of computer principles. Table 4 shows the average of Test (F) scores for the flipped classroom and the traditional classroom.

Table 4: Test (F) Scores' Average for Flipped Classroom and Traditional Classroom.

\begin{tabular}{|c|c|c|c|c|c|}
\hline & Sum of Squares & Df & Mean Square & F & Sig. \\
\hline Between Groups & 2283.507 & 16 & 142.719 & 1.146 & .442 \\
Within Groups & 996.333 & 8 & 124.542 & & \\
Total & 3279.840 & 24 & & & \\
\hline
\end{tabular}


In this study, some students made good headway throughout the semester. The traditional model causes the students to achieve grades that are lower than, or equal to, those who studied under the flipped classroom model. It can also be considered that the traditional model has better outcomes, when the traditional class has good students who do not have a flipped classroom model. These facts explain the proportion of students who have passed the subject in the traditional classroom. As a rule of thumb, students felt that the grading was fairer compared to the flipped model in the traditional system.

The same pattern was illustrated when the students were asked about the implementation. This shows that those differences in the students' grades were not only caused by the difference in the process of learning between both methods but were also a result of the differences in the students' abilities in the classroom. A student with high intelligence is going to receive a higher score, and that is going to be great after the process has been completed. Table 5 shows the values for successful students in a flipped classroom and in a traditional classroom.

Table 5: Values for Successful Students in a Flipped Classroom and a Traditional Classroom

\begin{tabular}{|l|r|r|r|r|r|r|}
\hline & T & Df & \multirow{2}{*}{$\begin{array}{c}\text { Sig. } \\
\text { (2-tailed) }\end{array}$} & $\begin{array}{c}\text { Mean } \\
\text { Difference }\end{array}$ & \multicolumn{2}{|c|}{$\begin{array}{c}\text { 95\% Confidence } \\
\text { Interval of the Differ- } \\
\text { ence }\end{array}$} \\
\cline { 5 - 7 } & & & & & Lower & Upper \\
\hline Successful students (Class A) & 16.487 & 11 & .135 & 38.58333 & 33.4325 & 43.7341 \\
\hline Successful students (Class B) & 16.523 & 11 & .135 & 37.08333 & 32.1435 & 42.0232 \\
\hline
\end{tabular}

This study stands in the same line as does the previous literature that, in the flipped classroom, students received higher scores than in the traditional classroom. Consequently, students will learn more when studying through the flipped classroom model compared to the traditional model.

\section{DISCUSSION OF QUESTIONNAIRE ANSWERS}

The results of the answers from only the flipped classroom students can be summarised as follows. The questionnaire had two parts: selecting options and responding to open questions. Questions 1 to 19 were closedended questions about the method implemented; the mean value was calculated for both ratings. The flipped classroom model promotes active self-learning and improves the skills that future teachers should learn to attain a better result than with the traditional model. Students from the flipped classroom responded positively to the question of whether or not the pre-recorded lectures had helped them understand, as they helped cover a wide range of learning styles. The efficiency of the flipped classroom may be greater than that of the traditional method due to the higher level of interaction between teachers and students. Under the flipped learning model, students can study before coming to the class, and during their next lecture, the teacher briefly explains the learning material and assigns tasks to the students and the chance to ask about any problems they may have encountered with the material.

As pertains to the students' level of agreement or disagreement with the flipped classroom model, the data was presented in terms of frequencies, averages, and standard deviation for the questionnaire questions, with the most frequent answers highlighted in light grey. From the data analysis, it can be concluded that the students felt that they had enough time to watch the videos outside of classes. The answers that showed the highest levels of agreement were question 10, related to the use of prerecorded lectures leading to a wide range of learning methods (mean=4.24), and question16 about the ease of solving the exercises proposed in flipped classes, no matter how the videos were viewed $($ mean $=4.52)$. The videos were seen as allowing the students to revisit the contents that they did not understand well, which is more difficult to do during a classroom session. 
Meanwhile, the questionnaire affirmation that recorded the highest levels of disagreement were questions 14 and 15 which were about the Internet connection provided in the college of Economic having enough time to watch the videos outside of classes (mean=2.12).

The flipped classroom is a comfortable way of teaching the subject and the study process (mean $=2.44$ ); some students who did not think that the pre-recorded lectures helped them were of that opinion because they believed that the videos had the same information that was contained in the textbook, while other students considered the use of videos to be advantageous. Some students who felt they were supported by the pre-recorded lectures noticed that the flipped classroom model was effective in teaching and learning. (mean $=4.04$ ), whereas others found them to be of benefit.

A few students, who claimed to have understood the subject without even viewing the videos or studying the theoretical content, tended to indicate that they had prior knowledge of the subject or answered the questions randomly when they were asked. $80.70 \%$ of students found the content in the videos to be helpful in solving exercises for test and exam preparation, and so more attention was paid to the videos than to the textbook. However, there was no teacher guidance for the students when they were doing their homework. The exercises required knowledge of content that was explained clearly in the videos, and viewing these videos required an Internet connection in the university. Using the flipped learning method is not a simple process that can simplify practices; it needs a more nuanced understanding of effective teaching methods to deal with the shift from conventional to flipped learning. Table 6 shows the answers of students to the questionnaire.

Table 6: Students' Answers to the Questionnaire

\begin{tabular}{|l|c|c|}
\hline \multicolumn{1}{|c|}{ Questions } & $\begin{array}{c}\text { \% of students whose } \\
\text { answers agreed } \\
\text { (strongly agree \& } \\
\text { agree) }\end{array}$ \\
\cline { 2 - 3 } & \multicolumn{2}{|c|}{$\begin{array}{c}\text { Percentage } \\
\text { Average }\end{array}$} \\
\hline $\begin{array}{l}\text { 1. The practical side was in the laboratory to explain components of the } \\
\text { computer principles. }\end{array}$ & $50.9 \%$ & 3.28 \\
\hline 2. The flipped classroom model was effective in teaching and learning. & $68.4 \%$ & 4.04 \\
\hline $\begin{array}{l}\text { 3. The flipped classroom paradigm encourages successful self-learning and } \\
\text { it improves the skills of students. }\end{array}$ & $57.9 \%$ & 3.68 \\
\hline \begin{tabular}{l} 
4. The topics of the computer principles course were interesting. \\
\hline 5. The number of problems presented in the classroom was enough.
\end{tabular} & $64.9 \%$ & 3.72 \\
\hline 6. Each issue was defined by the problem-solving conducted in the subject. & $54.9 \%$ & 3.70 \\
\hline $\begin{array}{l}\text { 7. Another work carried out by teamwork during class testing was neces- } \\
\text { sary. }\end{array}$ & $57.9 \%$ & 3.44 \\
\hline 8. The evaluation of homework, lessons and exams was fair. & $71.9 \%$ & 4.12 \\
\hline 9. The learning method was implemented well by the teacher. & $64.9 \%$ & 3.80 \\
\hline 10. Pre-recorded lectures led to a wide range of learning methods. & $75.4 \%$ & 4.24 \\
\hline $\begin{array}{l}\text { 11. Interactive elements are used in flipped learning, such as video, pdf files } \\
\text { and PowerPoint. }\end{array}$ & $66.7 \%$ & 4.00 \\
\hline
\end{tabular}




\begin{tabular}{|l|c|c|}
\hline $\begin{array}{l}\text { 12. There were interactions between teachers and students with the meth- } \\
\text { odology. }\end{array}$ & $45.6 \%$ & 3.08 \\
\hline 13. This approach can be used in other subjects in the computer sciences. & $70.2 \%$ & 4.08 \\
\hline 14. An Internet connection was provided in the college. & $36.8 \%$ & 2.88 \\
\hline 15. I did not have enough time to watch the videos outside of classes. & $15.8 \%$ & 2.12 \\
\hline $\begin{array}{l}\text { 16. I found it easy to solve the exercises proposed in flipped classes, no } \\
\text { matter how the videos were viewed. }\end{array}$ & $80.7 \%$ & 4.52 \\
\hline $\begin{array}{l}\text { 17. I took less time to perform the proposed exercises with the flipped } \\
\text { classroom. }\end{array}$ & $54.4 \%$ & 3.52 \\
\hline $\begin{array}{l}\text { 18. I found that the videos allowed me to revisit content when I didn't un- } \\
\text { derstand it well, which is more difficult to do in a traditional classroom. }\end{array}$ & $70.2 \%$ & 4.18 \\
\hline $\begin{array}{l}\text { 19. I consider the flipping learning model an advantage in the learning pro- } \\
\text { cess, and the teacher gives me more attention in the flipped classroom. }\end{array}$ & $68.4 \%$ & 3.94 \\
\hline
\end{tabular}

\section{THE OPINIONS OF STUDENTS ABOUT THEIR LEARNING UNDER THE FLIPPED LEARNINGMODEL}

Students from the flipped classroom answered an open question, Q20: What are the recommendations that they would suggest for the next course of flipped learning? They provided recommendations for the next lesson. Some students in the flipped classroom did not want to change the system applied because they were comfortable with that model. Other students had some demands, such as improving the Internet connection in the college and having more tables to place the computers on for every student in the laboratory. The video quality of the teaching videos, however, was not good, with the content unnoticeable at times, and there was no teacher guidance for students when doing their homework. The students agree on this point, and $64 \%$ of the students were of the view that using the flipped approach was good, and the video in solving the exercises was better. The method encouraged self-learning, and pupils were actively assuming their learning. In the flipped teaching model, the method encouraged self-learning, the students study the material at home by watching videos, reading, listing key points, and planning questions for their next lecture, during which they conduct some exercises to appreciate their teaching experience. Table 7 shows the students' opinions about learning with the flipped learning model.

Table 7: Students' Opinions about Learning with the Flipped Learning Model

\begin{tabular}{|l|c|c|}
\hline \multirow{2}{*}{$\begin{array}{c}\text { Recommendations that they would suggest for the next } \\
\text { course of flipped learning }\end{array}$} & $\begin{array}{c}\text { Percentage of student answers } \\
\text { for the recommendations they } \\
\text { would suggest for the next }\end{array}$ \\
\cline { 2 - 3 } & Yes & No \\
\hline $\begin{array}{l}\text { 1. Do the teachers in the Flipped classroom help students to } \\
\text { do their homework? }\end{array}$ & $71 \%$ & $29 \%$ \\
\hline $\begin{array}{l}\text { 2. Did you find the registered videos are good in solving the } \\
\text { exercises? }\end{array}$ & $64 \%$ & $36 \%$ \\
\hline
\end{tabular}




\section{CONCLUSION AND FUTURE RESEARCH}

The goal of this study was to investigate the effectiveness of the flipped classroom model and to enable students to learn their own skills and to motivate them and their interactions outside of the classroom, as well as encourage activities in the classroom for computer principles students at the Alasmarya Islamic University. Using technology in teaching and learning is not only limited to the use of videos, but also includes all emerging technology trends, such as flipped learning, blended learning, mobile learning, gamification, game-based learning, and online learning.

Based on the literature review and expert advice, the researchers outlined learning practises in the flipped-class model. Flipped classrooms vary in many ways from conventional classrooms, ranging from facilities and activities to consequences. This model is intended to increase student engagement in the classroom and can be extended to higher education in Libya. In the flipped classroom, the teacher is a facilitator who guides learners, where learners are always active participants of the educational process. The researchers consider the concept of the flipped classroom as an advantageous one in the learning process, and the student felt that teacher gave him more attention in the flipped classroom. Students need the necessary understanding to carry out exercises and need to repeat and revisit the information that is given to them. The students agree on this point and $64 \%$ of the students were of the view that using the flipped approach was good and the video in solving the exercises was better.

\section{LIMITATION}

Despite its limitations, as this study was in one subject with a small sample size, it expands the application awareness in computer-based concepts of the flipped classroom model. The model has shown that students embrace it positively and that it encourages self-learning, and students can study the pre-recorded lectures in advance. However, more qualitative and quantitative research should be done to recognise better how the potential of this model can be used.

\section{REFERENCES}

Ahmed, H. O. K. (2016). Flipped learning as a new educational paradigm: An analytical critical study. European Scientific Journal, 12(10). https://doi.org/10.19044/esj.2016.v12n10p417

Evseeva, A., \& Solozhenko, A. (2015). Use of flipped classroom technology in language learning. Procedia-Social and Behavioral Sciences, 206, 205-209. https://doi.org/10.1016/j.sbspro.2015.10.006

García-Ramírez, Y. (2019). Pavements course: Is the flipped classroom model effective in all cases? A case study in a developing country. Proceedings of the 15th International Conference on Web Information Systems and Technologies (WEBIST) - Volume 1: 2ETI, Vienna, Austria, (pp. 509-516). https://doi.org/10.5220/0008397705090516

Hsieh, J. S. C., Huang, Y. M., \& Wu, W. C. V. (2017). Technological acceptance of LINE in flipped EFL oral training. Computers in Human Behavior, 70, 178-190. https://doi.org/10.1016/j.chb.2016.12.066

Karabulut-Ilgu, A., Cherrez, N. J., \& Hassall, L. (2018). Flipping to engage students: Instructor perspectives on flipping large enrolment courses. Australasian Journal of Educational Technology, 34(4). https://doi.org/10.14742/ajet.4036

Le, T. Q., \& Do, T. T. A. (2019). Active teaching techniques for engineering students to ensure the learning outcomes of training programs by CDIO approach. International Journal on Advanced Science, Engineering and Information Technology, 9(1), 266-273. https://doi.org/10.18517/ijaseit.9.1.7959

Mulbar, U., \& Zaki, A. (2019, October). An experiment of reciprocal teaching model in higher education. Journal of Physics: Conference Series, 1317(1), p. 012134). IOP Publishing. https://doi.org/10.1088/1742$\underline{6596 / 1317 / 1 / 012134}$ 
O'Flaherty, J., \& Phillips, C. (2015). The use of flipped classrooms in higher education: A scoping review. The Internet and Higher Education, 25, 85-95. https:/ / doi.org/10.1016/j.iheduc.2015.02.002

Pastor, C. R., \& Howard, L. (2018). Using the flipped classroom model in teacher education - Is turning the tables the way forward? Aula de Encuentro, 20(2). https://doi.org/10.17561/ae.v20i2.10

Silva, A., \& Quadros-Flores, P. (2019). Mediated information and flipped classroom-information retention level assessment. International Journal of Advanced Engineering Research and Science, 6(8). https://doi.org/10.22161/ijaers.68.3

Soliman, N. A. (2016). Teaching English for academic purposes via the flipped learning approach. Procedia-Social and Behavioral Sciences, 232, 122-129. https://doi.org/10.1016/j.sbspro.2016.10.036

Suardika, I. K., Wiramihardja, E., \& Momo, A. H. (2016). Flipped classroom in the realm of higher education: Potential and challenges. International Journal of Education and Learning Systems, 1, 164-168. http://www.iaras.org/iaras/filedownloads/ijels/2016/002-0021.pdf

Sulisworo, D., Basriyah, K., Sari, L., \& Toifur, M. (2019). Comparing the effectiveness of flipped classroom and online learning on improving critical thinking skills in high school physics learning. In 6th International Conference on Community Development (ICCD 2019). Atlantis Press. https://doi.org/10.2991/iccd-19.2019.170

\section{AUTHORS}

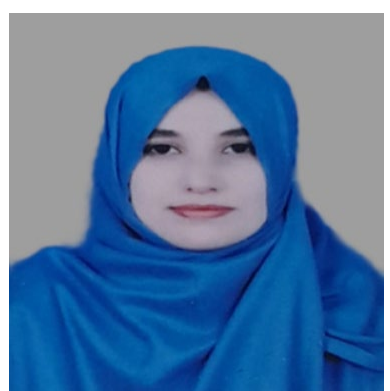

ing in higher education.
Entisar Al Ghawail (e.alghawail@,asmarya.edu.ly); (e tisar.alghawail@,fst.utm.tn) is a Lecture at Department of Information System at Information Technology collage of Alasmarya Islamic University- Libya. She had Bachelor of Science of Computer Science from Libya University, 1999 and MSc of Sciences at Information Systems Management, School of Computer and Engineering at the University of Huddersfield, UK, 2011. Now she is Candidate a PhD of Information at Faculty of Sciences of Tunis, University of Tunis El Manar, Tunisia Her research interests cover a broad range of educational technology, using of ICTs and e-learn-

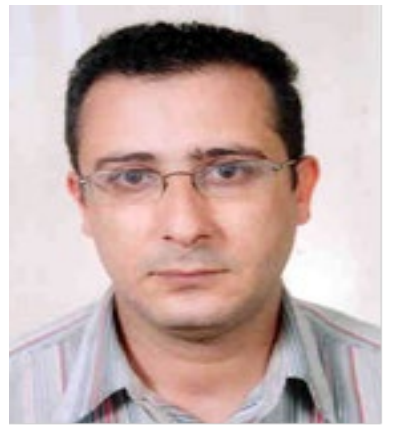

Sadok Ben Yahia (Sadok.ben@,taltech.ee) is a Professor at the Technology University of Tallinn (TalTech) since January 2019. He obtained his Habilitation to Lead research in Computer Sciences from the University of Montpellier in April 2009. His research interests mainly focus on combinatorial aspects in Big Data and their applications to different fields, e.g., Data mining, combinatorial analytics (e.g., maximum clique problem, minimal transversals), smart cities (e.g., information aggregation \& dissemination, traffic prediction). For the supervision activities, He supervised $30 \mathrm{PhD}$ Computer Science Students and more than 50 master students. A selected list of his publications is shown at a glance through his DBLP web site http://dblp.uni-trier.de/pers/hd/y/Yahia:Sadok Ben In addition, the impact of his publications within the community is shown through the google scholar https://scholar.google.com/citations?user=uJwhmiUAAAAJ\&hl=fr He is currently member of the steering committee of the International Conference on Concept Lattices and their Applications (CLA) as well as the International French Spoken Conference on Knowledge Extractions and Management. 